\title{
PENGARUH PARTISIPASI ANGGARAN DAN KEJELASAN SASARAN ANGGARAN TERHADAP KINERJA LAPORAN KEUANGAN DAERAH: STUDI KASUS PADA KANTOR BPKAD KOTA PALOPO
}

\author{
Nawanti Uppa \\ Program Studi Akuntansi, Universitas Muhammadiyah Palopo \\ Nawantiuppa12@gmail.com.
}

\begin{abstract}
ABSTRAK
Penelitian ini bertujuan untuk mengetahui Pengaruh Partisipasi Anggaran dan Kejelasan Sasaran Anggaran Terhadap Kinerja Laporan Keuangan Daerah. Jenis metode penelitian yang digunakan adalah penelitian kuantitatif yang merupakan jenis penelitian dengan tujuan untuk mengetahui seberapa besar pengaruh variabel bebas terhadap variabel terikat. Teknik analisis dan pengolahan data menggunakan analisis regresi linear berganda, uji parsial ( $t$ ), koefisien determinasi, dan uji simultan (f). Hasil penelitian menunjukkan bahwa secara simultan partisipasi anggaran dan kejelasan sasaran anggaran berpengaruh terhadap kinerja laporan keuangan daerah. Secara parsial partisipasi anggaran dan kejelasan sasaaran anggaran berpengaruh positif dan signifikan terhadap kinerja laporan keuangan daerah.
\end{abstract}

Kata kunci: Partisipasi, Sasaran, Kinerja

ABSTRACT

This study aimed to determine the Effect of Budget Participation and Clarity of Budget Goals on the Performance of Regional Financial Statements. The type of research method used is quantitative research, which is a type of research to determine how much influence the independent variable has on the dependent variable. Data analysis and processing techniques used multiple linear regression analysis, partial test $(t)$, coefficient of determination, and simultaneous test (f). The results showed that simultaneous budget participation and budget target clarity affect the performance of regional financial statements. Partially, budget participation and transparency of budgetary statements have a positive and significant effect on the performance of local financial reports.

Keywords: Participation, Goals, Performance

\section{PENDAHULUAN}

Reformasi tahun 1998 telah membuka wacana perubahan manajemen keuangan pemerintah. Terkait pelaksanaan otonomi daerah, pemerintah mengeluarkan Undang- Undang Nomor 32 Tahun 2004 yang telah diamandemenkan dengan Undang-Undang Nomor 23 Tahun 2014 tentang Pemerintahan Daerah mengenai penyelenggaraan pemerintahan daerah diarahkan untuk mempercepat terwujudnya kesejahteraan masyarakat melalui peningkatan pelayanan, pemberdayaan dan peran serta masyarakat dengan memperhatikan prinsip demokrasi, pemerataan, keadilan dan kekhasan suatu daerah. Sebagaimana diatur dalam Undang-Undang Nomor 33 Tahun 2004 tentang Perimbangan Keuangan antara Pemerintah Pusat dan Pemerintahan Daerah timbul hak dan kewajiban daerah yang dapat dinilai dengan uang sehingga perlu dikelola dalam suatu sistem pengelolaan keuangan daerah. Pengelolaan keuangan daerah sebagaimana dimaksud merupakan subsistem dari sistem pengelolaan keuangan negara dan merupakan elemen pokok dalam penyelenggaraan pemerintahan daerah. 
Peraturan Menteri Dalam Negeri Nomor 33 Tahun 2017 tentang pedoman penyusunan APBD merupakan pihak-pihak kebijakan sebagai petunjuk dan arah penyusunan anggaran bagi pemerintah daerah dalam penyusunan anggaran, pembahasan, dan penetapan APBD dan menjadi komitmen bersama agar akuntabilitas yang sudah diatur dapat bergerak dalam mengefisiensikan anggaran dan program yang ada.

Anggaran sebagai suatu rencana kegiatan dalam suatu periode yang direpresentasikan dalam bentuk rencana pendapatan dan belanja dalam satuan moneter yang berbentuk suatu dokumen yang menggambarkan kondisi keuangan dari pemerintahan yang meliputi pendapatan, belanja dan aktivitas (Sujarweni, 2015 : 28). Anggaran dapat dijadikan sebagai manifestasi dari rencana yang akan dicapai dimasa yang akan datang dan pada masa yang sama budget dapat menjadi alat kontrol. Kejelasan sasaran anggaran akan membantu aparat untuk mencapai suatu kinerja laporan yang baik dan transparan.

Pengelolaan keuangan pemerintah daerah harus dilakukan berdasarkan tata kelola kepemerintahan yang baik (good governance government), yaitu pengelolaan keuangan yang dilakukan secara transparan dan akuntabel, yang memungkinkan para pemakai laporan keuangan untuk dapat mengakses informasi tentang hasil yang dicapai dalam penyelenggaraan pemerintahan daerah. Laporan keuangan yang dihasilkan oleh pemerintah daerah akan digunakan oleh beberapa pihak yang berkepentingan sebagai dasar untuk pengambilan keputusan.

\section{TINJAUAN PUSTAKA}

\section{Partisipasi Anggaran}

Menurut Institute Biaya dan Akuntansi Manajemen (2014) secara terminologi "Anggaran adalah sebuah pernyataan keuangan dan atau kuantitatif disusun dan disetujui sebelum jangka waktu tertentu dari kebijakan yang akan ditempuh selama periode untuk memperoleh sasaran. (Maitland. 2000 dalam Abata 2014). Menurut Hansen Mowen(2011:423) Anggaran biasa menjadi salah satu alat yang paling penting untuk pengambilan keputusan dalam organisasi.

Partisipasi adalah keterlibatan individu yang bersifat mental dan emosional dalam kelompok bagi pencapaian tujuan bersama dan berbagi tanggung jawab bersama (Soetrisno, 2010). Partisipasi menunjukkan pada luasnya partisipasi bagi aparat pemerintah daerah dalam memahami anggaran yang telah diusulkan oleh unit kerjanya dan pengaruh tujuan pusat pertanggung jawaban Nawanti Uppa 66 |76 
anggaran mereka (Munawar, 2006).

Partisipasi penyusunan anggaran dilakukan dengan tujuan agar anggaran yang ditetapkan nantinya bisa sesuai dengan keadaan yang terjadi. Partisipasi penyusunan anggaran merupakan ciri dari penyusunan anggaran yang menekankan kepada partisipasi aparat pemerintah daerah untuk mempertanggung jawabkan proses penyusunan anggaran. Pada sektor publik, partisipasi anggaran dilakukan ketika antara pihak eksekutif, legislatif, dan masyarakat bekerja sama dalam pembentukan anggaran. Unit OPD (masing-masing instansi/dinas/kantor) membuat usulan-usulan yang kemudian disampaikan kepada Kepala Bagian, Kepala Bagian menyampaikan usulan tersebut kepada Kepala Daerah, kemudian Kepala Daerah bersama DPRD membahas anggaran tersebut, hasil dari pembahasan tersebut ditetapkan oleh Kepala Daerah sebagai anggaran yang tentunya dibuat sesuai dengan Peraturan Daerah yang berlaku.

\section{Kejelasan Sasaran Anggaran}

Menurut Kenis (1979) dalam Putra (2013) kejelasan sasaran anggaran merupakan sejauhmana tujuan anggaran ditetapkan secara jelas dan spesifik dengan tujuan agar anggaran tersebut dapat dimengerti oleh orang yang bertanggungjawab atas pencapaian anggaran tersebut.

Deddi Noerdiawan (2010 : 20) menyatakan bahwa penetapan tujuan spesifik akan lebih produktif daripada tidak menetapkan tujuan spesifik yang akan mendorong pegawai untuk melakukan yang terbaik bagi pencapaian tujuan yang dikehendaki. Adanya sasaran anggaran yang jelas, maka akan mempermudah untuk mempertanggungjawabkan keberhasilan atau kegagalan pelaksanaan tugas organisasi dalam rangka untuk mencapai tujuan-tujuan dan sasaran-sasaran yang telah ditetapkan sebelumnya. Sasaran yang tidak jelas dapat menyebabkan kebingungan, tekanan dan ketidakpuasan dari pegawai. Pimpinan organisasi dapat meningkatkan kepuasan kerja, menurunkan ketegangan kerja, dan memperbaiki anggaran yang dihubungkan dengan sikap, kinerja anggaran, dan efisiensi biaya. Oleh sebab itu, kejelasan sasaran anggaran daerah harus dinyatakan secara jelas, spesifik dan dapat dimengerti oleh mereka yang bertanggung-jawab untuk menyusun dan melaksanakannya.

Dalam penyusunan anggaran, sedapat mungkin anggaran yang disusun harus jelas sasaran yang ingin dicapai. Anggaran yang tidak jelas sasarannya, sudah dapat dipastikan akan menghadapi kesulitan dalam pelaksanaannya dan bahkan menjadi gagal. Untuk itu kejelasan sasaran anggaran 
akan mendorong manajer lebih efektif dan melakukan yang terbaik dibandingkan dengan sasaran yang tidak jelas (Hazmi dkk,2012). Bastian dalam Pangumbalerang dan Pinatik (2014) menyatakan bahwa kejelasan dan spesifikasi sasaran anggaran mempunyai dampak yang positif terhadap komitmen pencapaian sasaran dan timbulnya kepuasan terhadap karyawan.

Menurut penelitian Emilia (2013) dalam optimalisasi penganggaran dibutuhkan kejelasan sasaran kegunaannya. Anggaran yang tidak diketahui sasarannya akan mengakibatkan tidak sesuainya kegunaan dari anggaran yang semula direncanakan.

\section{Kinerja Laporan Keuangan Daerah}

Menurut Bastian (2006) indikator kinerja adalah ukuran kuantitatif dan kualitatif yang menggambarkan tingkat pencapaian suatu sasaran dan tujuan yang telah ditetapkan, dimana pengukuran atau indikator tersebut meliputi aspek-aspek antara lain indikator masukan (input), keluaran (output), hasil (outcome), manfaat (benefit), dan dampak (impact).

Laporan keuangan adalah hasil dari proses akuntansi yang dapat digunakan sebagai alat untuk berkomunikasi antara data keuangan atau aktivitas suatu perusahaan dengan pihak-pihak yang berkepentingan dengan data taktivitas perusahaan tersebut (Munawar), definisi lain tentang laporan keuangan oleh Farid dan Siswanto laporan keuangan merupakan suatu informasi yang diharapkan mampu memberikan bangunan kepada pengguna untuk membuat keputusan ekonomi yang bersifat financial.

Laporan keuangan memberikan informasi tentang sumber daya ekonomi dan kewajiban entitas pelaporan pada tanggal pelaporan dan arus sumber daya ekonomi selama periode berjalan. Informasi ini diperlukan pengguna untuk melakukan penilaian terhadap kemampuan entitas pelaporan dalam menyelenggarakan kegiatan pemerintahan di masa mendatang. Entitas pelaporan menyajikan informasi untuk membantu para pengguna dalam memperkirakan hasil operasi entitas dan pengelolaan aset, seperti halnya dalam pembuatan dan evaluasi keputusan mengenai alokasi sumber daya ekonomi (Aliyah dan Nahar, 2012)

\section{METODE PENELITIAN}

\section{Tempat dan Waktu Penelitian}

Penelitian ini dilakukan pada Kantor Badan Pengelolaan Keuangan dan Aset Daerah (BPKAD) 
Kota Palopo yang beralamat di jalan Jendral Sudirman Kota Palopo dengan jangka waktu penelitian kurang lebih dua (2) bulan.

\section{Jenis dan Sumber Data}

Jenis data yang digunakan dalam penelitian ini yaitu data kuantitatif yang merupakan data dalam bentuk angka dan diolah menggunakan aplikasi statistik. Sumber data dalam penelitian ini adalah data primer, yaitu data yang diperoleh melalui penjebaran kuesioner.

\section{Populasi dan Sampel}

a. Populasi

Populasi dalam penelitian ini adalah seluruh aparat pegawai pada Kantor Badan Pengelolah Keuangan dan Aset Daerah (BPKAD) Kota Palopo.

b. Sampel

Adapun sampel yang merupkan informan adalah aparat pegawai yang terlibat langgung pada penyusunan anggaran dari masing-masing bidang pada Kantor BPKAD Kota Palopo.

\section{Metode Pengumpulan Data}

Metode pengumpulan data menggunakan kuesioner agar diperoleh data yang relevan, dapat dipercaya, obyektif dan dapat dijadikan landasan dalam proses analisis. Kuesioner merupakan suatu teknik pengumpulan data secara tidak langsung (peneliti tidak langsung bertanya jawab dengan responden). Instrumen atau alat pengumpulan datanya juga disebut angket berisi sejumlah pertanyaan-pertanyaan yang harus dijawab atau direspon oleh responden. Responden mempunyai kebiasaan untuk memberikan jawaban atau respon sesuai dengan persepsinya. Data yang digunakan untuk menilai jawaban-jawaban yang diberikan dalam menguji variabel independen dan dependen terdiri dari lima tingkatan, (skala 1-5) untuk pernyataan positif alternatif jawaban yaitu: sangat setuju $(\mathrm{SS})=5$, setuju $(\mathrm{S})=4$, netral $(\mathrm{N})=3$, tidak setuju $(\mathrm{TS})=2$, dan sangat tidak setuju $($ STS $)=1$.

\section{Metode Analisis Data}

a. Statistik Deskriptif 
Prosedur analisa statistik deskriptif yang biasa digunakan untuk menjelaskan instrument reliabilitas dan validitas serta untuk melaporkan data dalam sebuah penelitian kuantitatif. Prosedur ini menggambarkan cara yang singkat untuk merangkum dan mengorganisasikan data yang telah dikumpulkan (Hamdi, 2014:95). Analisis statistik deskriptif ini melputi tabel,grafik, rata-rata (mean), standar deviasi, nilai maksimum, nilai minimum, dan jumlah penelitian sehingga penelitian ini menggunakan statistik deskriptif.

b. Uji Validitas

Uji Validitas merupakan hasil penelitian valid bila terdapat kesamaan antara data yang sesungguhnya terjadi pada objek penelitian, Sugiyono (2012).

c. Uji Reliabilitas

Reliabilitas merupakan adanya konsistensi dan stabilitas nilai hasil skala pengukuran tertentu. Pengujian reabilitas bertujuan untuk mewujudkan sejauh mana suatu pengukuran relatif.

\section{Pengujian Regresi Linear Berganda}

Metode yang digunakan dalam penelitian ini adalah regresi linear berganda. Untuk menyatakan hubungan antara variabel dependen dan variabel independen maka digunakan pengujian regresi linear berganda dengan rumus, Ghozali (2009).

$$
\mathrm{Y}=\alpha+\beta 1 \mathrm{X}_{1}+\beta 2 \mathrm{X}_{2}+\mathrm{e}
$$

Keterangan :

Y : Kinerja Laporan Keuangan Daerah

$\mathrm{X}_{1} \quad$ : Partisipasi Anggaran

$\mathrm{X}_{2}$ : Kejelasan Sasaran Anggaran

$\alpha \quad$ : Konstanta

$\beta \quad$ : Koefisien Regresi

e : Error 


\section{Pengujian Hipotesis}

a. Uji Parsial

Uji parsial digunakan untuk menguji koefisien regresi secara parsial dari variable independensinya.

b. Koefisien Determinasi

Koefisien determinasi digunakan untuk melihat seberapa besar pengaruh variabel independen atau variabel bebas dalam menerangkan secara keseluruhan terhadap variabel dependen atau variabel terikat serta pengaruhnya secara potensial dapat diketahui dari besarnya nilai koefisien determinasi.

c. Uji Simultan

Uji ini bertujuan untuk mengetahui apakah seluruh variable independen mempunyai pengaruh secara bersama-sama atau simultan terhadap variable dependen dengan menggunakan uji $\mathrm{F}$ dengan tarif signifikan 0,05 atau 5\%.

\section{HASIL DAN PEMBAHASAN}

\section{Analisis Hasil Penelitian}

Uji Hipotesis dalam penelitian ini menggunakan analisis regresi linear berganda yang meliputi uji koefisien determinasi $\left(\mathrm{R}^{2}\right.$ ), uji parsial (uji t) dan uji simultan (uji F) pengujian ini dilakukan untuk menguji hubungan antar variabel penelitian, mengetahui besarnya pengaruh masing-masing variabel bebas terhadap variabel terikat dan mengetahui apakah seluruh variabel bebas mempunyai pengaruh secara bersama-sama terhadap variabel terikat.Ringkasan hasil analisis regresi linear berganda disajikan pada tabel 4.6 dibawah ini.

Tabel 4.4 Analisis Regresi Linear Berganda

$\mathrm{Y}=17.801+0,249 \mathrm{X}_{1}+0,320 \mathrm{X}_{2}$

Coefficientt Statistic Sig

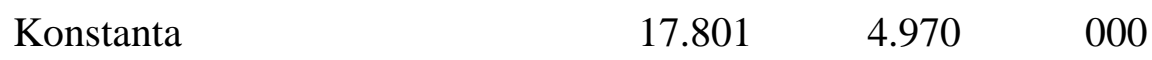


Partisipasi Anggaran

Kejelasan Sasaran Anggaran
249

320
2.095

2.148
044

039

$\mathrm{N}=50$

$\mathrm{R}^{2}=671$ Adj. $\mathrm{R}=415$

F-Statistic $=13.085=0,000^{\mathrm{b}}$

Sumber : Hasil Pengelolaan SPSS

1. Analisis Regresi Linear Berganda

Analisis regresi linear berganda digunakan untuk menghitung besarnya pengaruh antara variabel independen yaitu ,partisipasianggaran, dan kejelasan sasaran anggaran terhadap variabel dependen yaitu kinerja laporan keuangan daerah. Dari tabel 4.4 dapat dilihat model persamaan regresi berganda dengan menggunakan SPSS yaitu Unstandardized Coefficients, Hal tersebut akan dianalisis sesuai penjelasan berikut ini:

a. Nilai konstanta untuk persamaan regresi berdasarkan perhitungan statistik di atas sebesar sebesar 17.801 artinya apabila variabel bebas bernilai nol maka kinerja laporan keuangan daerah di Kantor BPKAD Kota Palopo tetap sebesar 17.801.

b. Nilai koefisien $\left(\beta_{1}\right)$ sebesar 0,249menunjukkan bahwa pengaruh partisipasi anggaran $\left(\mathrm{X}_{1}\right)$ terhadap kinerja laporan keuangan daerah (Y) adalah positif atau searah, artinya setiap peningkatan variabel partisipasi anggaran maka perilaku auditor akan mengalami kenaikan sebesar0,249 satuan.

c. Nilai koefisien $\left(\beta_{2}\right)$ sebesar 0,320menunjukkan bahwa pengaruh kejelasan sasaran $\operatorname{anggaran}\left(\mathrm{X}_{2}\right)$ terhadap kinerja laporan keuangan daerah $(\mathrm{Y})$ adalah positif atausearah, artinya setiap peningkatanvariabel kejelasan sasaran anggaran, maka perilaku auditor akan mengalami kenaikan sebesar0,320 satuan.

2. Hasil Uji Koefisien Determinasi $\left(\mathrm{R}^{2}\right)$

Dari tabel 4.4 koefisien determinasi yang ditunjukkan oleh Adj. $\mathrm{R}^{2}$ dari persamaan regresi menghasilkan nilai sebesar 0,415. Hal ini menunjukkan bahwa besarnya pengaruh yang diberikan oleh variabel independen yang terdiri daripartisipasi anggaran dan kejelasan 
sasaran anggaran, terhadap variabel dependen kinerja laporan keuangan daerah adalah sebesar 41,5 persen sedangkan sisanya sebesar 58,5 persen dipengaruhi oleh faktor lain yang tidak diteliti dalam penelitian ini. Hal ini mengartikan bahwa masih ada faktorfaktor lain yang sangat berpengaruh terhadap kinerja laporan keuangan daerah.

\section{Hasil Uji Parsial (Uji t)}

Uji t bertujuan untuk menguji pengaruh dari masing-masing variabel independen secara parsial terhadap variabel dependen. Untuk mengetahui bagaimana pengaruh tersebut dapat dilihat dengan membandingkan nilai probabilitas ( $p$-value) dari masing- masing variabel dengan tingkat signifikansi yang digunakan sebesar 0,05 dengan ketentuan Jika p-value< 0,05 dan nilai $\mathrm{t}$ hitung $\mathrm{t}$ tabel maka hal ini menunjukkan bahwa variabel-variabel independen secara parsial mempunyai pengaruh terhadap variabel dependen.Kriteria penelaian menggunakan degree of freedom $(\mathrm{df})=\mathrm{n}-\mathrm{k}$ dimana $\mathrm{n}$ adalah jumlah sampel dan $\mathrm{k}$ adalah konstruksi (variabel). Pada penelitian ini besarnya df $=50-3=47$ dengan $\alpha=$ 0,05 sehingga menghasilkan $\mathrm{t}_{\text {tabel }}=0.324$ Dari tabel 4.4 hasil pengujian antara variabel independen terhadap variabel dependen secara individu (parsial) adalah sebagai berikut:

a. Hipotesis pertama menyatakan bahwa partisipasi anggaranberpengaruh signifikan terhadap perilaku auditor. Dari tabel 4.4 dapat diketahui bahwa hasil pengujian untuk variabel partisipasi anggaran mempunyai probabilitas signifikan sebesar $0,000<0,05$. Dan nilai $\mathrm{t}$ hitung lebih besar dari $\mathrm{t}$ table $(2,095>0,324)$. Hal ini menunjukkan bahwa partisipasi anggaran mempunyai pengaruh signifikan terhadap kinerja laporan keuangan daerah.

b. Hipotesis kedua menyatakan bahwa pengalaman auditorberpengaruh signifikan terhadap perilaku auditor. Dari tabel 4.4 dapat diketahui bahwa hasil pengujian untuk variabel kejelasan sasaran anggaran mempunyai probabilitas signifikan sebesar $0,005<0,05$. Dan nilai $\mathrm{t}$ hitung lebih besar dari $\mathrm{t}$ tabel $(2,148>0,324)$. Hal ini menunjukkan bahwa kejelasan sasaran anggaran mempunyai pengaruh signifikan terhadap kinerja laporan keuangan daerah.

4. Uji Simultan (Uji F)

Dari tabel 4.4 Uji F ini bertujuan untuk mengetahui apakah seluruh variabel independen Nawanti Uppa 73 | 76 
mempunyai pengaruh secara bersama-sama atau simultan terhadap variabel dependen dengan menggunakan uji $\mathrm{F}$ dengan tarif signifikansi 0,05 atau 5 persen. Jika nilai signifikansi uji $\mathrm{F}$ lebih kecil dari 0,05 maka terdapat pengaruh antara semua variabel independen terhadap variabel dependen. Kriteria penelaian menggunakan df $1=\mathrm{k}-1$ dan df2 = n-k dimana $\mathrm{n}$ adalah jumlah sampel dan $\mathrm{k}$ adalah konstruksi (variabel). Pada penelitian ini besarnya df $1=3-1=2$ dan df $2=50-3=47$ dengan $\alpha=0,05$ sehingga menghasilkan $\mathrm{F}$ tabel $=2,79$. Berdasarkan uji $\mathrm{F}$ diperoleh hasil bahwa nilai $\mathrm{F}$ hitunglebih besar dari $\mathrm{F}$ tabel $(13,085>2,79)$ dengan nilai signifikan lebih besar dari tingkat signifikan $(0,000<0,05)$. Dengan demikian disimpulkan bahwa semua variabel independen dalam penelitian ini secara bersama-sama (simultan) berpengaruh signifikan terhadap variabel dependen.Hal ini berarti bahwa jika variable partisipasi anggaran $\left(\mathrm{X}_{1}\right)$ dan kejelasan sasaran anggaran $\left(\mathrm{X}_{2}\right)$ secara bersama-sama meningkat, maka kinerja laporan keuangan daerah(Y) juga akan meningkat. Begitu pun sebaliknya jika variabel partisipasi $\operatorname{anggaran}\left(\mathrm{X}_{1}\right)$ dan kejelasan sasaran anggaran $\left(\mathrm{X}_{2}\right)$ secara bersama-sama menurun, maka kinerja laporan keuangan daerah (Y) juga akan menurun.

\section{Pembahasan}

\section{Pengaruh partisipasi Anggaran terhadap Kinerja Laporan Keuangan Daerah}

Hasil penelitian yang telah dilakukan oleh peneliti dapat disimpulkan bahwa variabel Partisipasi Anggaran di uji secara parsial terhadap Kinerja Laporan Keuangan Daerah menghasilkan nilai signifikan sebesar 0,044 lebih kecil dari 0,05. Berdasarkan data tersebut, bahwa variabel Partisipasi Anggaran dalam penelitian ini berpengaruh secara positif dan signifikan terhadap variabel Kinerja Laporan Keuangan Daerah.

Berdasarkan hasil analisis regresi linear berganda diperoleh nilai $b_{1}$ sebesar 0,249 hal ini berarti Partisipasi Anggaran mempengaruhi Kinerja Laporan Keuangan Daerah sebesar 0,249 atau berpengaruh secara positif artinya Partisipasi Anggaran meningkat sebesar 1, maka berpengaruh terhadap Kinerja Laporan Keuangan Daerah sebesar 0,249.

\section{Pengaruh Kejelasan Sasaran Anggaran Terhadap Kinerja Laporan Keuangan Daerah}

Hasil penelitian yang telah dilakukan oleh peneliti dapat disimpulkan bahwa variabel Kejelasan Sasaran Anggaran di uji secara parsial terhadap Kinerja Laporan Keuangan 
Daerah menghasilkan nilai signifikan sebesar 0.039 lebih kecil dari 0,05. Berdasarkan data tersebut, bahwa variabel Kejelasan Sasaran Anggaran dalam penelitian ini berpengaruh secara positif dan signifikan terhadap variabel Kinerja Laporan Keuangan Daerah.

Berdasarkan hasil analisis regresi linear berganda diperoleh nilai $b_{2}$ sebesar 0,320 hal ini berarti Kejelasan Sasaran Anggaran mempengaruhi Kinerja Laporan Keuangan Daerah sebesar 0,320 atau berpengaruh secara positif Kejelasan Sasaran Anggaran meningkat sebesar 1, maka berpengaruh terhadap Kinerja Laporan Keuangan Daerah sebesar 0,320.

\section{PENUTUP}

\section{Kesimpulan}

Berdasarkan data yang didapatkan setelah diolah maka diperoleh hasil analisis penelitian mengenai pengaruh partisipasi anggaran dan kejelasan sasaran anggaran terhadap kinerja laporan keuangan daerah, maka dapat disimpulkan sebagai berikut :

a. 1. Berdasarkan hasil pengujian hipotesis diperoleh hasil yaitu variable Partisipasi Anggaran (X1) berpengaruh signifikan terhadap Kinerja Laporan Keuangan Daearah (Y). Hasil ini diperkuat dengan adanya hasil Uji $\mathrm{T}$ (parsial) dimana diperoleh nilai signifikan sebesar 0,044 lebih kecil daripada 0,05.

b. Berdasarkan hasil pengujian hipotesis diperoleh hasil yaitu variabel

Kejelasan Sasaran Anggaran (X2) berpengaruh signifikan terhadap Kinerja Laporan Keuangan Daerah. Hasil ini diperkuat dengan adanya hasil Uji T (parsial) dimana diperoleh nilai signifikan sebesar 0,039 lebih kecil dari pada 0,05.

\section{Saran}

Setelah mengadakan penelitian pada Kantor BPKAD Kota Palopo tentang Pengaruh Partisipasi Anggaran dan Kejelasan Sasaran Anggaran Terhadap Kinerja Laporan Keuangan Daerah, maka berdasarkan apa yang dialami penulis selama melakukan penelitian ini menyampaikan saransaran sebagai berikut:

1. Kepada Kantor BPKAD Kota Palopo diharapkan meningkatkan kinerja laporan keuangan pemerintah, dan menghasilkan pengukuran kinerja yang lebih baik, serta menfasilitasi manajemen keuangan/asset yang lebih transparan dan akuntabel. 
2. Kepada peneliti selanjutnya, agar dapat mengembangkan penelitian selanjutnya dengan meneliti factor-faktor lain yang dapat mempengaruhi kinerja laporan keuangan daerah.

\section{DAFTAR ISI}

Dwipuspasari, Evi. 2011. Analisis Peneraapan Psak 33 (Revisi 2011) Akuntansi Pertambangan Umum Pada PT. Bukit Asam ( Persero ) Tbk. Skripsi. Depok: Fakultas Ekonomi Universitas Indonesia.

Fardani, Andi. 2012. Dampak Sosial Keberadaan PT Vale Indonesia Tbk Terhadap Kehidupan Masyarakat (Studi Kasus Sorowako Kecamatan Nuha Kabupaten Luwu Timur ). Skripsi. Makassar: Fakultas Sosial dan Ilmu Politik Universitas Hasanuddin Makassar.

Ghozali, Imam dan Chairi, Anis. 2007. Teori Akuntansi, Edisi Ketiga. Semarang: Badan Penerbit Universitas Dipenegoro.

Ikatan Akuntan Indonesia. 2012. Standar Akuntansi Keuangan. Jakarta: Ikatan Akuntan Indonesia.

Kurniawan, Rizkie Arie. 2017. Dampak Kebijakan Perizinan Pertambangan Terhadap Kerusakan Lingkungan Bukit Camang Bandar Lampung. Skripsi. Bandar Lampung: Fakultas Ilmu Sosial Dan Politik Universitas Lampung.

Martani, Dwi et al., 2014. Akuntansi Keuangan Menengah Berbasis PSAK. Jakarta: Salemba Empat.

Pamungkas, Noto dan Rusherlistyani. 2015. Penerapan IFRS 6 dalam Psak 64. Journal Of Economic \& Social Vol: 1 No. 1 Hal: 67-77. (Diakses Tanggal 01 Desember 2018).

Pernyataan Standar Akuntansi Keuangan (PSAK) No. 33 Tahun 2011 tentang Aktivitas Pengupasan Lapisan Tanah dan Pengelolaan Lingkungan Hidup Pada Pertambangan Umum.

Pernyataan Standar Akuntansi Keuangan (PSAK) No. 64 Tahun 2011 tentang Eksplorasi dan Evaluasi Sumber Daya Mineral.

Riveta, Oksidea. 2012. Implementasi Psak No. 64 Tentang Perlakuan Akuntansi Biaya Eksplorasi dan Evaluasi (Studi Kasus pada PT. Medco Energi International Tbk). Jurnal Ilmiah Mahasiswa Fakultas Ekonomi dan Bisnis. Vol: 1 No. 2. (Diakses Tanggal 13 Desember 2018).

Rustanto, Bambang. 2015. Penelitian Kualitatif Pekerjaan Sosial. Bandung: PT Remaja Rosdakarya.

Sugiyono. 2009. Metode Penelitian Kuantitatif, Kualitatif Dan R\&D. Bandung: Alfabeta.

Sugiyono. 2012. Metode Penelitian Kuantitatif, Kualitataif, Dan R\&D. Bandung. Alfabeta.

Yusuf, A. M. 2017. Metode Penelitian. Jakarta: Penerbit Fajar Interpratama Mandiri. 